\title{
LECTURER' STRATEGIES IN TEACHING SPEAKING ON ONLINE LEARNING DURING PANDEMIC COVID-19
}

\author{
${ }^{1}$ Mike Amelia, ${ }^{2}$ Fitri Handayani \\ ${ }^{1}$ Universitas Bina Sarana Informatika, ${ }^{2}$ Universitas Mahaputra Muhammad Yamin \\ 1ameliamike@yahoo.co.id, ${ }^{2}$ fhandayani17@co.id
}

\begin{abstract}
This study intends to investigate lecturers' practices for teaching speaking in online learning during pandemic COVID-19. For Lecturer, online learning has posed a new challenge, particularly in the area of teaching speaking. To make the lesson more exciting, the lecturer requires a strategy and should be able to mix it with online learning media. The research was descriptive qualitative study. The study focused on two UNSIKA-speaking lecturers. For the study, the researcher employed observation and interviews as instruments. According to the findings of the study, lecturers employ a variety of strategies to teach speaking, including podcasts, debates, and story-telling, retelling, dialogue, and drama. The lecturer combined some media in learning: whatsapp, zoom, microsof team, google meet, google classroom, youtube and edmodo.
\end{abstract}

Keywords: Teaching Strategies, Online learning, Pandemic covid-19

\section{Introduction}

The corona virus disease (Covid-19), which has afflicted many countries around the world, poses unique issues for educational institutions, particularly colleges. Scenarios must be used in lectures to avoid physical contact between students and lecturers, as well as between students and other students (Firman, 2020). As a result, pupils should do online studying from home. Online learning is defined as learning that uses the internet to bring students and lecturers together to conduct learning exchanges (Kuntarto, 2017). People, living things, things, and anything else that the instructor can employ as an intermediary to provide learning content are examples of tools or learning media in traditional learning. This will, of course, be very different from online learning; because the connection between teachers and students in online learning is limited by distance, extra learning resources, such as accompanying media, will be required to make learning more efficient and effective.

The following are the points that lecturers should consider when teaching from home: 1) Online learning offers a learning experience that is free of the demands of an achievement curriculum for promotion and graduation; 2) Online learning focuses on life skills education; and 3)3) Activities and learning tasks should be varied to take into account the learners' existing facilities; 4) The results of students' work are given qualitative feedback and useful from the teacher (Lestari, 2020). Furthermore, (Adhe, 2018) claims that online learning can be very effective because it is full of feedback responses and because learners can collaborate on formal learning activities while also studying independently. Personalization: this learning model can be customized to meet the needs of students so that all students can receive the same quality as the teacher's instructions.

To prepare a lesson, the lecturer must prepare learning strategies and plan ahead of time, emphasizing the importance of learning strategies that are more creative and innovative as well as simple so that learning objectives can be met to the fullest extent possible. Whether successful or not, the process of a teacher learning has attempted to change students' behavior from not knowing to knowing. In the teaching and learning process, the lecturer must identify and determine the best strategy to apply. Methods and 
strategy must be determined in accordance with the learning material to be provided and the learning objectives so that students may understand them readily. According to (Jayanti, 2020), the teacher's endeavor to implement previously defined learning approaches in order to attain the intended goals is referred to as a learning strategy. During the Covid-19 pandemic, learning tactics will be based on online learning and will be able to collaborate on both blended and traditional learning. However, it is not a simple assignment for the lecturer, as numerous issues arise.

There are a number of issues that develop when students are not learning at school. The period of the epidemic is separated into three parts: pedagogy, technology, and economy (Nurkolis \& Muhdi, 2020). Lack of training, lack of experience, low ICT mastery, time constraints, and lack of parental concern in assisting children in learning are pedagogy-related issues, while technology-related issues include: lack of infrastructure in the form of internet/wifi networks, weak signal, and lack of parental concern in assisting children in learning. Then there's the issue of the economy, which includes, among other things, the relatively expensive cost of a quota or data package. These problems also happened in teaching speaking at UNSIKA during the pandemic of COVID-19. Although every human being can speak, speaking skills are not a form of skill that can be passed down from generation to generation. Formal speaking abilities, on the other hand, necessitate extensive training and supervision. When compared to other language skills, speaking is a sort of productive skill that occurs directly and expressively, making it challenging to utilize this skill in online learning. As a result, lecturers must be inventive in developing online learning strategies for teaching speaking, particularly in pandemic situations.

Lecturers' teaching activities can be made much easier with the use of useful and auxiliary teaching tools, and lecturers' enthusiasm for teaching can be recalled. Speaking skills material must be presented in an engaging manner to motivate students to learn it. The following are some media options that can assist teachers in delivering more innovative material using cutting-edge technology (Harahap, 2021): 1) The internet.Students can use Zoom Meeting, Google Meet, Messenger, Google Talk (used to hold online classes) and other applications to collect data from various sources for any instruction to improve speaking skills, and students can use Zoom Meeting, Google Meet, Messenger, Google Talk (used to hold online classes) and other applications to connect with friends, classmates, teachers, and even native speakers. This method of learning over the internet has been shown to improve students' verbal abilities and to compensate for a lack of native speakers in the area where students live. Furthermore, online conferencing improves intercultural awareness, motivation, and interaction. 2) EXPLAIN.TELL refers to the use of computer technology, including as hardware, software, and the internet, to improve language teaching and learning. This provides students with access to all available technology to aid in their English language learning. Students can use an online dictionary, communicate, and keep up with current events from around the world. 3) A podcast is a collection of audio or video files that can be downloaded or uploaded. Podcasts can assist students in becoming more comfortable with listening to English, and teachers can use them as useful audio assets in the classroom for activities such as discussions. Additionally, students can listen to a podcast that covers pronunciation for English students. Students can use podcast media to improve their speaking pronunciation. Students can use their technology-based entertainment system for instructional purposes thanks to podcasting. 4) The Quick Link Pen is a pen that allows you to quickly connect two items.It allows students to copy and save printed text and Internet links. This allows the reader to learn the definition of a term in the dictionary contained, facilitating data flow to the computer. 5) The Quicktionary. It is a pen-shaped translation device. This allows students to scan a word rapidly and acquire its meaning and translation on its own LCD panel.

According to (Hussain, 2017), the following functions-based exercises and assignments can be used to improve speaking skills:1) Dialogue is a classroom technique for practicing language skills such as greeting, agreeing, disagreeing, apologizing, recommending, and asking for information.2) Role play is a common strategy for practicing speaking skills in the classroom, where the students play their roles. 3) 
Thoughts/Ideas. Students are asked to give their ideas regarding a topic that is being discussed when we seek for opinions on difficult themes or circumstances. Students can express themselves in a variety of languages. Problems (group work) are a fantastic way to get students to speak up. While attempting to solve the problem. 5) Surveys and interviews are another useful function-based strategy in which an interviewer or surveyor attempts to learn about a person's test, preferences, attitudes, and information. 6) Goals or aspirations. Every student should have goals and aspirations. This could be a good way to interact. This practice came to an abrupt conclusion, prompting many students to speak up. 7) Music. The students appreciate the songs, and they can be used to improve EFL speaking abilities. For example, this may be a lovely way to practice simple inquiry forms. 8) Retelling a story.(Fitri \& Endang Komariah, 2017) demonstrates that after implementing the retelling technique with video, students' speaking skills have significantly improved. It indicates that using video to recount a story can be one of the teacher's alternate strategies for teaching speaking.

Another strategy in teaching speaking is found in (Arbain \& Nur, 2017). Find some techniques. 1) show and tell. When using this strategy, the lecturer needed a pair of students to take turns exhibiting and telling their assignment preparation. Furthermore, both observations one and two revealed this method. 2) Presentation: In a presentation, individual students give a lecture about a single topic or person. Students must be given time to gather information and organize it appropriately in this case. Students should be assigned a listening assignment, such as providing feedback, while listening to a presentation. 3) Drama. Drama is the formation of a dialogue between two or more students. It can be done outside and inside of the classroom, and 4) a question and an answer.

It can be determined from the preceding application strategy that the English lecturer used those strategies in teaching speaking. It denotes that the lecturer employed those strategies in order to suit the pupils' needs. What should be done with intermediary equipment such as computers, cellphones, gadgets, and data packages, as well as wifi, in the process of online learning, especially in speaking activities, if a pandemic of COVID-19 occurs. The use of technology and software to carry out this learning process, which is extremely beneficial to education, for example: 1) WhatsApp. WhatsApp is a popular messaging service that is widely utilized on the internet. WhatsApp is a prominent online messaging service that is widely utilized. WhatsApp allows people to form groups based on their needs, which may be used for conversation, information exchange, and learning. Teachers can utilize WhatsApp to create virtual classroom discussion groups as part of the Contextual Teaching Learning paradigm, which integrates a form of learning community as a result of which students' motivation can increase in online learning in the era and post-pandemic Covid-19 by using WhatsApp to increase learners' motivation (Susilawati \& Supriyatno, 2020). Zoom is a video conferencing platform that prioritizes innovation. Zoom, like Google Hangout, can be used for online learning, especially by teachers who prefer face-toface engagement over the internet. Meetings, webinars, conference calls, file sharing, and online learning may all be done with Zoom. The success of using zoom is determined by the strength of the internet signal received by the user, as stated by (Laili, 2020). The utilization of Zoom Meeting is not quite effective because of network issues that produce internet voice and a lack of student grasp of the topic being presented. Furthermore, rehearsing discussions in couples or groups is tough. Zoom, on the other hand, is superior to other educational platforms since it allows for distant learning and classroom-like conversation.. 3) Microsoft Teams. (Rojabi, 2020) discovered that online learning via Microsoft Teams is something new for students, but that this interaction and learning environment attracted students to participate in online learning, and as a result, they were able to absorb the learning materials more easily. 4) Google meet.(Fakhruddin, 2020) revealed that using Google Meet as a teaching medium in English speaking activities was an effective technique to improve students' speaking skills during the pandemic covid-19. 5) Google Classroom: During a pandemic, Google Classroom is one of the most effective forms of media. Because Google Classroom can fully engage students' talents in finding, comprehending, exploring, analyzing, and developing learning outcomes, it is one of the learning media based on inquiry learning approaches (Abd. Ghofur,2018).6) Edmodo (Wicaksono, 2018) states that students' motivation in learning can be improved by using Edmodo.

The usage of technology is a problem for most teachers or lecturers during a pandemic, particularly for UNSIKA lecturers who must be able to use it in the teaching and learning process. As a result, the 
researcher became intrigued and began to examine the topic by observing and determining how lecturers deal with challenges in teaching English in an online speaking environment.

\section{Research Methoodology}

The study relied on descriptive qualitative research to examine lecturer strategies for speaking English in an online learning class. It explains the speaking strategies employed by UNSIKA's speaking lecturer. Two UNSIKA speaking lecturers were the subjects of the study. The researcher used the following instruments: 1Observation is an engagement that begins with observing and ends with recording, which is efficient, intelligent, evenhanded, and level headed towards various types of wonders in both actual and artificial situations (Kristanto, 2018). Through zoom, Microsoft teams, Google meetings, and direct observation, the researcher observed and saw the lecturer teaching, and took note. 2) Interview.The researcher asks the informant about the things that have been prepared beforehand. The researcher has conducted interviews with two speaking lecturers. The researcher also did documentation and field note to strengthen the data.

\section{Findings and Discussion}

Researchers analyzed the strategies used by the speaking lecturers in the process of online learning. Based on the results of data collection and analysis, the researchers found several strategies used in the online speaking learning process, namely English Podcast, debate, story-telling, retelling, dialogue, and drama.

\section{The English Podcast}

One of the most popular language learning applications for speaking is English Podcast. It is an interesting application that can be downloaded through a smartphone. The students can learn many speaking skills, such as: pronunciation practice, conversation practice, building vocabulary, phrases, idioms, the use of some expressions, and speaking exercises. Based on researcher observation, the lecturer sends some announcements to the students via WhatsApp Group. The lecturer asked the students to download an English podcast application on their smartphones. Ask the students to comprehend and learn about a certain topic in an English podcast in 15 minutes. Next, the lecturer discussed the topic through Edmodo. The lecturer asks the students to tell him about what they have learned from the English Podcast in their own words and discuss the topic. Finally, the lecturer gives some quizzes and games for students to stimulate their motivation to practice speaking.

\section{Lecturer 1:}

'English Podcast make my students easy to comprehend the material. The students can practice their pronounciation by listening native speaker. They can learn many thing in this application. This application is very simple and could motivate my students to speak english even I also 2.Debate stimulate their motivation to practice speaking at the end of the lesson by giving some games.

Debate is considered as a variation of a speaking activity to enrich students' experience. The form of debate is arguing ideas pro and contra. Based on the researcher's observations of the speaking class, the lecturer used a Zoom meeting to hold a debate. Before doing the debate activity, the lecturer explains the topic about which they agree and disagree, shares some topics to be debated, and gives one week to students to find articles related to the topic chosen to enrich their knowledge. The students are divided into 2 groups. One group is pro, and another is contra to the topic (motion). Each group discusses their own part. Then, in the Zoom meeting, the lecturer asks each group in turn to deliver their ideas and try to pretend their opinion. When they have finished debating, the lecturer and the students come to a conclusion and decide the winner of the group. The lecturer gave reward to the winner of the group and decided on the best speaker in the form of participation. During debating activities, the students appear to be very enthusiastic. 
Students should be able to communicate English fluently through argument in debate activity. A contentious topic may serve as a motivator for them to speak up. Everyone has their own opinion on a subject. It used to be difficult for them to say something due to a lack of vocabulary or pronunciation. However, the more views they have, the better they are able to communicate in English. It's fun and tough to teach speaking through discussion. They were routinely conveying their ideas in English, despite mistakes in pronunciation and a lack of vocabulary that made their speech so protracted and with so many pauses. This is the purpose of these activities: to hear the students' voice to speak. How to choose a topic that is both interesting and familiar is a very crucial factor.

\section{Storytelling.}

Story telling is one of the strategies that the teacher utilizes in the spoken learning process. This storytelling intends for students to share their experiences or stories. Before asking the students to undertake story telling, the lecturer demonstrates some techniques for doing story telling via a Microsoft team meeting and a modeling task. The lecturer then provides the students a list of narrative stories to choose from and asks them to read the stories. The students then use any type of media aid, such as an engaging background, animation, or constructed puppets, to deliver the story. The lecturer instructed the students to practice at home until they were comfortable with it. The lecturer then instructed them to submit their performance on YouTube and share the link with the Whatsapp group. The audience listened to their friends' performance. Next, the lecturer then evaluated each presentation by assigning a score to it. (Pronunciation, intonation, grammar, vocabulary, correctness, and fluency were all scored using the speaking scoring rubric.) Following the presentation, there were questions and responses about the story's moral importance. The lecturer and the students came to an agreement on the story's content and presentation by giving comments and suggestions on the you tube link presentation of the students. While employed in the spoken learning process, storytelling tactics can boost students' vocabulary and inspire them to use their imagination when telling stories. This remark is supported by the findings of an interview performed by the researcher with one of the English speaking lecturers.

Lecturer2:

"My students are very anthusiasm when doing story telling activity. It really surprise me that they can do their performance attractively and it was very interesting. They used many properties like puppet, dolls, pictures or online animation. They use their imagination to make their presentation become better and it could develop the vocabulary, I also give some suggestion and comment about their performance it makes them become motivated to improve their speaking skill", Lecturer 2).

\section{Retelling}

Retelling is an effective teaching method for encouraging students to communicate and improving oral language comprehension. It allows readers to distinguish between main ideas and supporting information, and it aids students in comprehending the text's content. It encourages students to understand the plot, setting, and characters in the story. The lecturer used retelling to teach non-fiction reading text material. such as news, scientific text, and articles from journals. The lecturer gives students one week to prepare for the retelling activity. The lecturer gives some texts to the students on Google Classroom and asks them to choose one of the texts that they like most. The students are asked to comprehend the text first and take a note about some important points of the text. After that, they are asked to retell the text using their own words and record their performance on video. Finally, the students have to submit their performance to Google Classroom and the lecturer gives some feedback about the students' performance. Based on an interview with the speaking lecturer, retelling could improve students' critical reading and enhance their comprehension of the content of the text.

Lecturer 3:

" Retelling makes my students can develop their critical thinking, they make their own perception about the text and try to share the ideas by using their own words"

5.Dialogue 
Dialogue is one of the teaching strategies which is the most popular in speaking. The lecturer can increase the students' understanding of some speaking theories by practicing using dialogue or conversation activities. The speaking lecturer of UNSIKA used the dialogue in terms of speaking material, such as: the use of expressions in speaking, both in formal and informal situations. According to the researcher's observations. The lecturer explained the theory first using Edmodo, for example, like expressing likes and dislikes and modelling some examples of short dialogue using video, and then asked them questions related to the video. Finally, the lecturer asks the students to practice and make their own examples by using dialogue. The lecturer divided the group that consisted of two students and asked them to do a short and simple dialogue directly using the material given. The dialogue happened spontaniously at that time. The students are free to decide the topic of the dialogue. The lecturer gives some reward or point participation to students who perform the dialogue. The students were very enthusiastic about performing their dialogue. It could be seen that at the end of the learning, there were still many students who felt disappointed because they did not get the opportunity to perform their dialogue.

\section{Drama}

Drama is one of the strategies used by lecturers in teaching speaking. Based on observations of the teaching-speaking process by the researcher, The lecturer first explains the material to the students using Google Meet. Then the lecturer asked the chairman to divide the class into several groups. The students can choose the members of their group by themselves to make sure they become familiar with them. The lecturer lets the class choose the topic of drama and lets them create their own scenarios in their groups, such as situations, issues, events, and background. The drama should include the material that the lecturer has explained before. The group were asked to visit places such as malls, cafetarias, gardens, libraries, and book stores to make the drama become more realistic and asked them to record their performance. Before they perform the drama, the group should prepare the scenario first with their group. This also becomes one of the collaborative group work activities for them to practice and to discuss their speaking. After recording their drama, the students are asked to upload it to YouTube and share the link with the Whatsapp group class. Finally, the lecturer and the class will give some feedback about the students' performance in the Whatsapp group.

The data shows that the strategy used by the lecturer in teaching speaking is effective in improving students' motivation in speaking. It could be seen from the students' enthusiasm in giving feedback and comments about their friends' activities in speaking in comment columns. The researcher found that the students' enthusiasm while speaking through debate activity in a Zoom meeting. Debate can stimulate students to speak by giving their argumentation and defending their opinion. This finding is supported by (Reni Rosianna Lumbangaol, 2020) the research subjects' debating method demonstrates a development in the pupils' speaking abilities. It is clear that the pupils' capacity to ask questions, provide explanations, and answer them increased. The students' activities in class when debating improved greatly and significantly. It demonstrates that the debating technique has increased students' capacity to ask questions and provide explanations when speaking.

The next strategy used by the lecturer is story-telling to support the materials in class and make students more interested in learning to speak English. The students appear to be enthusiastic about the teaching and learning process, according to the researcher's observations. When students are trained to speak in a storytelling style, they learn to understand what the speaker is saying, memorize it, and appreciate the tale in class. As per research conducted by Ikrammudin (2017), storytelling is a strategy that helps students improve their speaking skills by expanding their vocabulary, enhancing their creativity, improving their pronunciation, and organizing their thoughts. Despite their initial difficulties, many students try to speak up by recalling a passage from the story or using their own words. Even if some students find speaking English challenging, they should practice. 
Another strategy that seems similar to story telling is retelling. The speaking lecturer is also used for retelling activities in teaching speaking for some non-fiction material. According to earlier research conducted by (Fitri \& Endang Komariah, 2017), using video to recount a story has a favorable influence on students' speaking ability. After watching the video, they were able to speak freely using their own words. Students' motivation to learn can be improved by using video. They were eagerly anticipating the following video. As a result, it may serve as a motivator for pupils to appreciate their learning experience. Next strategy used by the speaking lecturer was dialogue. Based on previous study conducted by (Sahib, 2019)The use of dialogue-games in English classes with a focus on speaking skills improved the students' ability to communicate. The survey also discovered that the participants are eager to learn. (Ananto \& Rusmiati, 2018) found that another strategy used in speaking is drama. Drama not only improved students' speaking skills but also piqued their interest in studying English, allowing them to overcome their fear of speaking. They were more confident in actively speaking and had a high level of participation in both inside and outside the classroom speaking activities.

The use of the strategy above was combined with online learning media such as Zoom, Google Meet, Microsoft Teams, Google Classroom, Whatsapp, and YouTube. (Harahap, 2021) states that there are a number of factors that can influence a student's ability to learn new abilities in speaking. Lecturers must pay attention to the media options that will be used in delivering online material because motivation plays an important role in the process of students learning speaking skills through online learning. Not only is motivation a factor for learning continuity, but media is also a factor for motivation.

\section{Conclusion}

Teaching English during Pandemic COVID-19 is not an easy job. It has become a challenge for a lecturer to use online learning media in teaching. A good lecturer has to be able to design their own teaching strategy for online learning. Based on the findings of the research, it can be concluded that there are some strategies used by the lecturers in speaking: Emglish Podcast, debate, story telling, retelling, dialogue, and drama. The lecturer combined some media in learning: whatsapp, zoom, microsof team, Google Meet, Google Classroom, You Tube and Edmodo. However, compared to previous investigations, the current research has a sense of security. The commonality is that e-learning causes issues with the connections that are utilized to access the e-learning platform. It is suggested that the students or lecturers make sure to strengthen their connection of internet before conducting online learning.

\section{References}

Abd. Ghofur. (2018). Using Google Classroom on Inquiry Based Learning to Student' Learning Participation. Jurnal Penelitian Pendidikan, 10 no 2, 1503-1509.

Adhe, K. R. (2018). Pengembangan Media Pembelajaran Daring Matakuliah Kajian PAUD di Jurusan PG PAUD. Journal of Early Childhood Care and Education, 1(1), 26.

Ananto, U. A., \& Rusmiati, I. (2018). Teaching Speaking Using Drama to Improve Students' Speaking Skill at SMK Negeri 2 Karawang. PROJECT, vol 1 no 4.

Arbain, A., \& Nur, D. R. (2017). Techniques for Teaching Speaking Skill in Widya Gama Mahakam University. Script Journal: Journal of Linguistic and English Teaching, 2(1), 13. https://doi.org/10.24903/sj.v2i1.80

Fakhruddin, A. (2020). USING GOOGLE MEET IN TEACHING SPEAKING. Journal of English Language Learning (JELL), vol 2 no2, 43-46. https://media.neliti.com/media/publications/318831using-google-meet-in-teaching-speaking-76ca8806.pdf

Firman, F. \& S. R. (2020). Pembelajaran Online di Tengah Pandemi Covid-19e. Indonesian Journal of Educational Science (IJES), vol 2 no 2. https://doi.org/https://doi.org/10.31605/ijes.v2i2.659

Fitri, S., \& , Endang Komariah, and H. H. (2017). Improving Students' Speaking Skill By Retelling Technique Using Video. Research in English and Education (READ), Vol 2, No, 36-45. http://jim.unsyiah.ac.id/READ/article/view/7163/3181 
Harahap, T. A. (2021). Improving Students' Motivation through English Online Learning: Speaking Skills. PROJECT, vol 4 no 5.

Hussain, S. (2017). Teaching Speaking Skills in Communication Classroom. International Journal of Media, Journalism and Mass Communications, 3(3). https://doi.org/10.20431/2454-9479.0303003

Ikrammudin, R. (2017). Using Story Telling Technique To Improve Speaking Ability [Ar-Ranyry State Islamic University Darussalam]. https://core.ac.uk/download/pdf/293467043.pdf

Jayanti, D. (2020). Strategi pembelajaran dimasa pandemi covid-19 di tk sartika ii sumurgenuk babat lamongan. http://digilib.uinsby.ac.id/45478/2/Dewi Jayanti_D98216031.pdf

Kristanto, V. H. (2018). Buku Metodologi Penelitian Pedoman Penulisan Karya Tulis Ilmiah (KTI). CV Budi Utama.

Kuntarto, E. (2017). Keefektifan Model Pembelajaran Daring Dalam Perkuliahan Bahasa Indonesia di Perguruan Tinggi. Indonesian Language Education and Literature ILEaL, vol 3 No 1. https://www.syekhnurjati.ac.id/jurnal/index.php/jeill/article/view/1820

Laili, R. N. N. (2020). The Use of Zoom Meeting for Distance Learning in Teaching English to Nursing Students during Covid-19 Pandemic. UHAMKA International Conference on ELT and CALL(UICELL), 235-244. file:///C:/Users/ASUS/Downloads/6290-Article Text-17039-1-1020210131.pdf

Lestari, Y. (2020). Pemanfaatan Jbclass Untuk Meningkatkan Motivasi Belajar Bahasa Inggris Peserta Didik Selama Masa Pandemi Covid-19 Using Jbclass To Enhance the Students 'Motivation in Learning English During Covid-19 Pandemic. 5(1), 114-122. https://jurnaldikpora.jogjaprov.go.id/index.php/jurnalideguru/article/download/150/164/

Nurkolis, N., \& Muhdi, M. (2020). Keefektivan Kebijakan E-Learning berbasis Sosial Media pada PAUD di Masa Pandemi Covid-19. Jurnal Obsesi : Jurnal Pendidikan Anak Usia Dini, 5(1), 212. https://doi.org/10.31004/obsesi.v5i1.535

Reni Rosianna Lumbangaol, M. R. M. (2020). Improving Students' Speaking Ability through Debate Technique. Celtic: A Journal of Culture, English Language Teaching, Literature and Linguistics, Vol. 7, No. https://ejournal.umm.ac.id/index.php/celtic/article/view/13674/pdf_1

Rojabi, A. R. (2020). Exploring EFL Students' Perception of Online Learning via Microsoft Teams: University Level in Indonesia. English Language Teaching Educational Journal, vol 3 no2. http://journal2.uad.ac.id/index.php/eltej/article/view/2349

Sahib, N. (2019). Using dialogue-games in Improving Speaking Ability of participants of advanced level of PIKIH Program. Jurnal Linguistik, 1, 19-30.

Susilawati, S., \& Supriyatno, T. (2020). Online Learning Through WhatsApp Group in Improving Learning Motivation in the Era and Post Pandemic COVID -19. Jurnal Pendidikan: Teori, Penelitian, Dan Pengembangan, 5(6), 852. https://doi.org/10.17977/jptpp.v5i6.13670

Wicaksono, R. (2018). The Student's Perception on the Use of Edmodo To Motivate Students To Learn. Universitas Muhammadiyah Yogyakarta. 